\title{
The role of metabolic syndrome in the induction of chronic pancreatitis after a first attack of acute pancreatitis - multicenter trial
}

\author{
Martina Bojková1, 2, Petr Dítě1, 2, Lumír Kunovský3, 4,5, Martin Blaho1, 2, Bohuslav Kianička, ${ }^{5,6}$, Ivo Novotný7, \\ Magdalena Uvírová8, Jana Dvořáčková2, 8, Jiří Dolina ${ }^{3,5}$, Marie Přecechtělováa ${ }^{3,5}$, Hana Mašková3, 5 , \\ Vladimír Procházka ${ }^{4,5}$, Pavel Janeček ${ }^{4,5}$, Oldřich Motyka ${ }^{9}$, Arnošt Martínek', 2 \\ 'Department of Internal Medicine, Department of Gastroenterology, University Hospital Ostrava, Ostrava, \\ Czech Republic \\ ${ }^{2}$ Faculty of Medicine, University of Ostrava, Ostrava, Czech Republic \\ ${ }^{3}$ Department of Gastroenterology and Internal Medicine, University Hospital Brno, Brno, Czech Republic \\ ${ }^{4}$ Department of Surgery, University Hospital Brno, Brno, Czech Republic \\ ${ }^{5}$ Faculty of Medicine, Masaryk University, Brno, Czech Republic \\ ${ }^{6} 2^{\text {nd }}$ Department of Internal Medicine, Department of Gastroenterology, St. Anne's University Hospital, Brno, \\ Czech Republic \\ ${ }^{7}$ Department of Gastroenterology, Masaryk Memorial Cancer Institute, Brno, Czech Republic \\ ${ }^{8}$ CGB Laboratory, a. s., Ostrava, Czech Republic \\ ${ }^{9}$ Nanotechnology Centre, VŠB - Technical University of Ostrava, Ostrava, Czech Republic
}

Background: Metabolic syndrome is a serious societal problem worldwide. In the Czech Republic more than $30 \%$ of the adult population are sufferers. The role of recurrent acute pancreatitis in the induction of chronic pancreatitis, following the so-called „mechanistic definition" of chronic pancreatitis, has been unequivocally confirmed. However, there are a number of factors that may contribute to the development of chronic pancreatitis. The first aim of the study was to determine whether the metabolic syndrome may affect the development of chronic pancreatitis. The second question we asked ourselves was whether even one acute attack of pancreatitis could be an inductive factor in chronic pancreatitis.

Methods: Based on data obtained retrospectively from a total of 264 people diagnosed with chronic pancreatitis in 4 centers, a total of 59 people (22.3\%) diagnosed within 36 months of a first attack of acute pancreatitis was obtained. Etiologies of either genetically induced pancreatitis or autoimmune pancreatitis were excluded. Diagnostics to identify the presence of metabolic syndrome were run on the 59 persons so obtained using the criteria from the so-called "harmonized" definition of 2009 (obesity, arterial hypertension, hypertriglyceridemia, type 2 diabetes mellitus and a decreased level of HDL cholesterol). Results: Comparing the findings of the individual components of metabolic syndrome in persons with chronic pancreatitis after a 1st attack of acute pancreatitis with the metabolic syndrome and in persons with chronic pancreatitis after the 1st attack of acute pancreatitis but without metabolic syndrome, a statistically significant difference in obesity was found ( $82.5 \%$ vs. $28.5 \%)$, hypertriglyceridemia ( $82.3 \%$ vs $17.8 \%$ ) and arterial hypertension (70.5\% vs $21.4 \%)$. The interval during which chronic pancreatitis occurred after acute pancreatitis averaged 12 months (10-14 months) in subjects with metabolic syndrome, whereas in the group without metabolic syndrome the interval was longer, 20 months (16-29 months). Conclusion: Our results show that even one attack of acute pancreatitis (regardless of etiology) can be an inductive factor in chronic pancreatitis. The presence of metabolic syndrome can accelerate the development of chronic pancreatitis after one has had acute pancreatitis.

Key words: acute pancreatitis, chronic pancreatitis, metabolic syndrome, obesity, hypertriglyceridemia, diabetes mellitus, hypertension, cholesterol. 


\section{Role metabolického syndrome v indukci chronické pankreatitidy po první atace akutní pankreatitidy - multicentrická studie}

Úvod: Metabolický syndrom patři mezi závažný celosvětový společenský problém. V České republice trpí tímto onemocněním více než $30 \%$ dospělé populace. Role rekurentní akutní pankreatitidy v indukci pankreatitidy chronické, ve shodě s mechanistickou definicí chronické pankreatitidy, byla jednoznačně potvrzena. Existuje však řada faktorů, které mohou přispět k rozvoji chronické pankreatitidy. Prvním cílem studie bylo zjistit, zda metabolický syndrom může mít vliv na rozvoj chronické pankreatitidy. Druhou otázku jsme si položili, zda i jedna prodělaná ataka pankreatitidy akutní, může být vyvolávající faktor pankreatitidy chronické. Metody: Na základě retrospektivnězískaných dat celkem od 264 osob, které jsou dispenzarizovány s diagnózou chronické pankreatitidy ve 4 centrech, byl získán soubor celkem 59 osob (22,3\%) s chronickou pankreatitidou diagnostikovanou do 36 měsíců od prvé ataky pankreatitidy akutní. Vyloučena byla etiologie pankreatitidy geneticky indukované a pankreatitidy autoimunitní. Ze získaného souboru 59 osob byla provedena diagnostika metabolického syndromu na základě splnění kritérií tzv. harmonizované definice z roku 2009 (obezita, arteriální hypertenze, hypertriglyceridémie, diabetes mellitus 2. typu a snižená hladina HDL cholesterolu). Výsledky: Při porovnání nálezů jednotlivých komponent metabolického syndromu u osob s chronickou pankreatitidou po 1. atace akutní pankreatitidy s metabolickým syndromem a u osob s chronickou pankreatitidou po 1. atace akutní pankreatitidy bez metabolického syndromu, byl nalezen statisticky významný rozdíl v zastoupení obezity $(82,5 \%$ v.s. $28,5 \%$ ), hypertriglyceridémie ( $82,3 \%$ v.s. 17,8 \%) a arteriální hypertenze (70,5\% v.s. 21,4\%). Interval, během kterého došlo ke vzniku chronické pankreatitidy po akutní pankreatitidě, u osob s metabolickým syndromem činila průměrná doba 12 měsíců (10-14 měsíců), zatímco u skupiny bez př́tomnosti metabolického syndromu byl časový interval delší, činil 20 měsíců (16-29 měsíců).

Závěr: Naše výsledky ukazují, že i jedna ataka akutní pankreatitidy (bez ohledu na etiologii), může být vyvolávajícím faktorem pankreatitidy chronické. Př́tomnost metabolického syndromu může akcelerovat rozvoj chronické pankreatitidy po prodělané pankreatitidě akutní.

Klíčová slova: akutní pankreatitida, chronická pankreatitida, metabolický syndrom, obezita, hypertriglyceridémie, diabetes mellitus, hypertenze, cholesterol.

\section{Introduction}

Metabolic syndrome is a major societal problem globally. In the Czech Republic more than 30\% of the adult population suffers from the disease. Metabolic syndrome, according to the globally accepted definition issued in 2009 (1), regularly involves five components: obesity, arterial hypertension, hypertriglyceridemia, type 2 diabetes mellitus and a decreased level of HDL cholesterol. Positivity for three of these traits is required to determine metabolic syndrome. Metabolic syndrome is a condition that is very closely associated with the development of cardiovascular disease, but equally, metabolic syndrome is a significant risk factor in the etiology of gastrointestinal, liver, pancreatic, and gastrointestinal cancers in general. Metabolic syndrome is one of the factors in the development of non-alcoholic fatty pancreas disease (NAFPD) $(2,3)$. This condition is accompanied by the development of type 2 diabetes mellitus, parenchymal fibrotisation, and in recent years there have been increasing reports of pancreatic cancer in the field of $\operatorname{NAFPD}(4,5)$.

The etiological factors of chronic pancreatitis are part of the classification of chronic pancreatitis, referred to as the TIGARO classification (6). In the last decade several studies have been published demonstrating the development of chronic pancreatitis in individuals with a history of acute pancreatitis. The first study concerning the role of acute pancreatitis in the development of chronic changes was published in 1994 by Ammann et al. (7). However, only in the last few years has the role of recurrent acute pancreatitis in the induction of chronic pancreatitis been unequivocally confirmed regardless of the etiology of acute pancreatitis $(8,9)$. This fact is part of the recently published so-called mechanistic definition of chronic pancreatitis (10).

Results differ as to how high a percentage of people go through a chronic form of the disease after suffering from an attack of acute pancreatitis. Studies performed by Lankische et al. describe the progression into the chronic form in only $4 \%$ of all patients (11). However, Nojgaard (12) and Takeyama (13) described conversion from an acute form of the disease to chronic pancreatitis in $15 \%$ and $24 \%$ of patients.

Naturally, not all patients will suffer from chronic pancreatitis after an attack of acute pancreatitis. Undoubtedly many other factors exist which can contribute to the development of chronic pancreatitis, e.g. the size of the pancreatic necroses, possible complications in the course of acute pancreatitis, etc.

\section{Material and methods}

The aim of our study was to determine the presence and possible role of metabolic syndrome and its components in the development of chronic changes in people with chronic pancreatitis after a first attack of acute pancreatitis. Based on data obtained retrospectively from a total of 264 people diagnosed with chronic pancreatitis in 4 centers, a total of 59 people (22.3\%) who were diagnosed within 36 months of a first attack of acute pancreatitis was obtained. In all 4 of these centers the European guidelines for the diagnosis of chronic pancreatitis were used (14). The diagnosis of chronic pancreatitis was based mostly on imaging modalities (CT, MRI, EUS) with a combination of laboratory markers (malnutrition, fecal elastase-1). These patients had never been 
diagnosed with chronic pancreatitis until their attack of acute pancreatitis. According to the new "mechanistic definition" (10) of chronic pancreatitis, the initial stages of chronic pancreatitis cannot be determined, because at that time they have no clinical, only histological correlates at the cellular level and markers of tissue immunity. The etiology of genetically induced pancreatitis and autoimmune pancreatitis was excluded. Consequently, a diagnosis of metabolic syndrome was established on the basis of fulfilling the criteria of the so-called "harmonized" definition issued in 2009 (1). The data was collected retrospectively during the period from 2015 until 2017. Statistical calculation was performed by means of the khí quadrate test (the level of statistical significance that was chosen was $p=0.05)$.

\section{Results}

In a group of 59 patients in whom chronic pancreatitis was proven to be etiologically dependent on acute pancreatitis, the average age was 54 years (43-64 years). By gender, there were 32 men (54.2\%) and 27 women (45.8\%). Alcohol predominated in the etiology of the pancreatitis (52.5\%). As for alcoholic etiology of the pancreatitis, the men were dominant (37.3\%), while in the case of the patients suffering from the biliary form of pancreatitis the women were dominant (27.1\%) (Tab. No. 1). In the group of 59 persons suffering from chronic pancreatitis after a first attack of acute pancreatitis, we diagnosed a subgroup of 16 patients (27.1\%), mostly obese individuals, who had a diagnosis of metabolic syndrome in addition to that of chronic pancreatitis. The other subgroup consisted of 28 patients (47.6\%) with chronic pancreatitis diagnosed after a first attack of acute pancreatitis but without the presence of metabolic syndrome. In 15 patients (25.3\%) the diagnosis of metabolic syndrome and a follow-up could not be performed for several reasons (some patients had moved away or they were not willing to be included in the study).

The diagnosis of metabolic syndrome was determined on the basis of meeting the criteria of the so-called harmonized definition from 2009 (1).

In the group of persons with an alcoholic etiology of their pancreatitis, of the components of the metabolic syndrome obesity was present in $29.4 \%$, hypertriglyceridemia and arterial hypertension in one third, and type 2 diabetes mellitus was found in $47.0 \%$ of the subjects. (Tab. No. 2).
In the group of patients with a biliary etiology of their pancreatitis, compared to the alcoholic etiology, the proportion of obesity was significantly higher, namely $52.9 \%$. We found arterial hypertension and hyperglycemia in $29.4 \%$ of the subjects. Hypertriglyceridemia was diagnosed in $52.9 \%$ of patients. (Tab. No. 2).

In all, regardless of the etiology of the pancreatitis, in the 16-member group of people suffering from chronic pancreatitis after a first attack of acute pancreatitis with metabolic syndrome, obesity was present in $82.3 \%$ of the subjects. At the same time, $82.3 \%$ had hypertriglyceridemia as well. Arterial hypertension was found in $70.5 \%$. Type 2 diabetes mellitus was found in $76.5 \%$ and a decrease in $\mathrm{HDL}$ cholesterol was found in one third of the subjects (Tab. No. 2).

We compared this group with the group of 28 patients suffering from chronic pancreatitis after a first attack of acute pancreatitis but without the presence of metabolic syndrome. In this group of people, regardless of the etiology of their pancreatitis, obesity was found in only $28.5 \%$ of the patients, type 2 diabetes mellitus was diagnosed more frequently, i.e. in $46.4 \%$. Hypertriglyceridemia was also present in a significantly smaller number of patients, compared to persons with metabolic syndrome, which turned out to be in 17.8\% (Tab. No. 3).

Comparing the two groups, a statistically significant difference was found in obesity, hypertriglyceridemia and arterial hypertension. We therefore believe that these components play a crucial role in the development of the process from acute inflammation of the gland to the stage of chronic pancreatitis, without metabolic syndrome (Tab. No. 4).

Finally, when evaluating the interval during which chronic pancreatitis occurred after acute pancreatitis, the mean time in subjects with metabolic syndrome was 12 months (10-14 months), while in the group without metabolic syndrome the time interval was longer, 20 months (16-29 months).

\section{Discussion}

In 1992, Kloeppel and Maillet (9) published their necrosis-fibrosis sequence hypothesis. It was a pathologist's view of the development of chronic pancreatitis from acute pancreatitis. The basis was a process of fibrotisation of initially necrotic tissue, leading to histomorphological and functional changes in pancreatic tissue. An important observation

Tab. 1. Chronic pancreatitis in patients after 1 attack of acute panreatitis (no. 59)

\begin{tabular}{|l|c|c|c|}
\hline Aetiological factors & Alcohol & Biliary & Idiopathic \\
\hline & $31(52.5 \%)$ & $24(40.7 \%)$ & $4(6.8 \%)$ \\
\hline Gender (male) & $22(37.3 \%)$ & $8(13.6 \%)$ & $2(3.4 \%)$ \\
\hline Gender (female) & $9(15.2 \%)$ & $16(27.1 \%)$ & $2(3.4 \%)$ \\
\hline
\end{tabular}

Tab. 2. Risk factors - chronic pancreatitis - subgroup with metabolic syndrome - after 1 attack of acute pancreatitis (no. 16)

\begin{tabular}{|l|c|c|c|c|}
\hline & & Alcohol & Biliary & Idiopathic \\
\hline Obesity (BMI) & $>30.0$ & $5(29.4 \%)$ & $9(52.9 \%)$ & 0 \\
\hline HDL cholesterol & $>1.3 \mathrm{mmol} / \mathrm{L}$ & $4(23.5 \%)$ & $2(11.7 \%)$ & 0 \\
\hline Glycaemia & $>5.6 \mathrm{mmol} / \mathrm{L}$ & $8(47.0 \%)$ & $5(29.4 \%)$ & $6(35.2 \%)$ \\
\hline Art. hypertension & $>130 \mathrm{~mm} \mathrm{Hg}$ & $6(35.3 \%)$ & $5(29.4 \%)$ & $13(76.5 \%)$ \\
\hline & $>90 \mathrm{~mm} \mathrm{Hg}$ & $5(29.4 \%)$ & $4(23.5 \%)$ & $1(5.9 \%)$ \\
\hline Triacylglyceridemia & $>1.7 \mathrm{mmol} / \mathrm{L}$ & $5(29.4 \%)$ & $9(52.9 \%)$ & 0 \\
\hline
\end{tabular}


Tab. 3. Chronic pancreatitis after 1 attack of acute pancreatitis - without metabolic syndrome (no. 28)

\begin{tabular}{|l|c|c|c|c|}
\hline & & Alcohol & Biliary & Total \\
\hline Obesity (BMI) & $>30.0$ & $3(10.7 \%)$ & $5(17.8 \%)$ & $8(28.6 \%)$ \\
\hline HDL cholesterol & $<1.3 \mathrm{mmol} / \mathrm{L}$ & $2(7.1 \%)$ & $4(14.3 \%)$ & $6(21.4 \%)$ \\
\hline Glycaemia & $>5.6 \mathrm{mmol} / \mathrm{L}$ & $9(32.1 \%)$ & $4(14.3 \%)$ & $13(46.4 \%)$ \\
\hline Art. hypertension & $>130 \mathrm{~mm} \mathrm{Hg}$ & $3(10.7 \%)$ & $3(10.7 \%)$ & $6(21.4 \%)$ \\
\hline & $>90 \mathrm{~mm} \mathrm{Hg}$ & $3(10.7 \%)$ & $3(10.7 \%)$ & $6(21.4 \%)$ \\
\hline Triacylglyceridemia & $>1.7 \mathrm{mmol} / \mathrm{L}$ & $2(7.1 \%)$ & $3(10.7 \%)$ & $5(17.8 \%)$ \\
\hline
\end{tabular}

Tab. 4. Comparison of patients with and without metabolic syndrome

\begin{tabular}{|c|c|c|c|}
\hline & $\begin{array}{c}\text { Metabolic syndrome } \\
- \\
\text { (no. 16) }\end{array}$ & $\begin{array}{c}\text { Metabolic syndrome } \\
- \\
\text { (no. 28) }\end{array}$ & P-value* \\
\hline & Positive & Negative & \\
\hline Obesity (BMI > 30) & $82.3 \%$ & $28.5 \%$ & $P<0.01$ \\
\hline HDL cholesterol & $35.2 \%$ & $21.4 \%$ & NS. \\
\hline Hyperglycaemia & $76.5 \%$ & $46.4 \%$ & NS. \\
\hline Art. hypertension & $70.5 \%$ & $21.4 \%$ & $P<0.01$ \\
\hline Hypertirglyceridemia & $82.3 \%$ & $17.8 \%$ & $P<0.01$ \\
\hline
\end{tabular}

and conclusion in this context is that acute pancreatitis is not a diffuse, but rather a focal process, with the presence of changes that are subsequently known from the histomorphological picture of chronic pancreatitis.

The original view was that only very rarely is acute recurrent biliary pancreatitis a factor in the development of chronic pancreatitis, in contrast to the alcoholic form of acute pancreatitis (15). The explanation was as follows: while alcoholic acute pancreatitis histomorphologically affects the whole glandular parenchyma, in the case of the biliary form the changes are localised mainly in the peripancreatic region, without any response in the pancreatic tissue. Changes in pancreatic tissue are the main factor in glandular fibrotisation.

In our study we proved, as in the studies of Yadava (16) and Takayema (13) that the development of chronic pancreatitis from acute pancreatitis is not uncommon in the case of the biliary etiology of the disease, not just alcoholic. A number of studies have shown that smoking, in addition to alcohol, is a risk factor for the development of chronic pancreatitis from acute pancreatitis $(12,13)$. Why some people develop chronic pancreatitis after acute pancreatitis and others do not has been the subject of a number of studies $(17,18)$. Sandzen (19) published the so-called "hypothesis of the two strikes in the induction of chronic pancreatitis". The first "strike" is the presence of metabolic, genetic and external factors combined with the influence of other possible risk factors, e.g. smoking, to together create the changes which turn into chronic pancreatitis.

In 2015, Berlinsson et al. published a retrospective study evaluating a total of 1457 individuals after their first attack of acute pancreatitis (20). $48 \%$ of cases of acute pancreatitis were of biliary etiology, $17 \%$ of alcoholic etiology. Less than $10 \%$ of cases of acute pancreatitis were evaluated as the severe form of the disease. The risk factors for the progression from the acute form to chronic form were determined to be smoking, alcohol and the seriousness of the acute pancreatitis.

The meta-analytical studies performed by Sakarana et al. (21) after evaluating 19 previous works showed that $10 \%$ of people became chronic after a first attack of acute pancreatitis, $36 \%$ of people with acute recurrent pancreatitis ended up with chronic pancreatitis. Alcohol, smoking and male gender are listed as risk factors in the study.

A Dutch multicenter study evaluated data obtained from 669 patients after the individuals had acute pancreatitis in 15 different Dutch hospitals (22). After the first episode of acute pancreatitis the chance of pancreatitis relapsing was found to be $17 \%$, and within 5 -years $7.6 \%$ were diagnosed with chronic pancreatitis.

In the set of 59 persons suffering from chronic pancreatitis after their first episode of acute pancreatitis, we diagnosed a subgroup of 16 patients who were diagnosed with metabolic syndrome. Metabolic syndrome is a condition that is involved in gastroenterology in the development of gastroesophageal reflux (23) and Barrett's esophagus (24) but is mainly associated with the finding of non-alcoholic hepatic steatosis (NAFLD - non-alcoholic fatty liver disease) and non-alcoholic steatohepatitis (NASH - non-alcoholic steatohepatitis) (25, 26). Adipocytokines play an important role in the pathogenetic process similar to the inductive of a spectrum of pancreatic changes - non-alcoholic steatopancreatitis, acute or chronic pancreatitis (27-30).

In our study, we showed that in the persons suffering from chronic pancreatitis after a first attack of acute pancreatitis the presence of metabolic syndrome plays an important role. Obesity, hypertriglyceridemia, arterial hypertension and diabetes mellitus (though the results concerning diabetes mellitus were on the border of statistical significance) are among the particularly important components of metabolic syndrome in the induction of pancreatic changes. In 2018, work performed by Melitas et al. (31) was published which presents 3 patients with the metabolic syndrome, steatopancreatitis and hypertriglyceridemia who developed chronic pancreatitis. The possible role of alcohol in the induction of pancreatic changes was excluded in all subjects. The authors, in accordance with our findings, refer to the important role of hypertriglyceridemia. In therapeutic practice, prevention of metabolic syndrome is important in preventing the induction of chronic pancreatitis (32) which arises in connection with those who have an attack of acute pancreatitis. The presence of metabolic 
syndrome is a possible factor in the faster progression of the changes from an acute to a chronic pancreatic form.

We are aware the evaluated set and its results can be influenced by the errors of small numbers, due to this fact the described findings have a certain limitation and further studies with a bigger set is needed to confirm the findings in this article.

\section{Conclusion}

1) In the development of chronic pancreatitis, in accordance with the mechanistic definition of chronic pancreatitis, acute pancreatitis is an etiological factor, not only in the form of acutely recurrent acute pancreatitis but even after one, clinically relevant acute pancreatitis.

\section{REFERENCES}

1. Albertin $K G$, Eckel RH, Grundy SM, et al. Harmonizing the metabolic syndrome: a joint interim statement of the International Diabetes Federation Task Force on epidemiology and Prevention, National Heart, Lung and Blood Institute, American Heart Association World Heart Federation, International Atherosclerosis Society and International Association for the Study of Obesity. Circulation 2009; 120(16): 1640-1605

2. Singh RG, Yoon HD, Wu LM, et al. Ectopic fat accumulation in the pancreas and its clinical relevance: A systemic review, meta-analysis and meta-regression. Metabolism 2017; 69: 1-18 3. Catanzaro R, Cuffari B, Italia A, et al. Exploring the metabolic syndrome: Nonalcoholic fatty pancreas disease. World J Gastroenterol 2016; 14: 22(34): 7660-7675.

4. Arslan AA, Helzlsouer KJ, Kooperberg C, et al. Anthropometric measures, body mass index and pancreatic cancer: a pooled analysis from the Pancreatic Cancer Cohort Consortium (PanScan). Arch Intern Med 2010; 170: 791-802.

5. Aune D, Greenwood DC, Chan DS, et al. Body mass index abdominal fatness and pancreatic cancer risk: a systematic review and non-linear dose-response meta-analysis of prospective studies. Ann Oncol 2012; 23: 843-852.

6. Etemad B, Whitcom DC. Chronic pancreatitis: diagnosis, classification and new genetic developments. Gastroenterology 2001; 120(3): 682-707.

7. Ammann RW, Muellhaupt B. Progression of alcoholic acute pancreatitis to chronic pancreatitis. Gut 1994; 35(4): 552-556.

8. Pelli H, Lappalainen-Neto R, Piironen A, et al. Risk factors for recurrent acute - alcoho associated pancreatitis: a prospective analysis. Scand J Gastroenterol 2008; 43(5): 614-621 9. Kloeppel G, Maillet B. The morphological basis for the evolution of acute pancreatitis into chronic pancreatitis. Virchows Archiv A Pathol Anatomy 1992; 420(1): 1-4. 10. Whitcomb D, Frulloni L, Garg P, et al. Chronic pancreatitis: An international draft consensus proposal a new mechanistic definition. Pancreatology 2016; 16: 218-224.

12. Nojgaard C, Becker U, Matzen P, et al. Progression from acute to chronic pancreatitis: prognostic factors, mortality and natural course. Pancreas 2011, 40(8); 1195-1200.

13. Takeyama Y. Long term prognosis of acute pancreatitis in Japan. Clin Gastroenterol Hepatol 2009; 7 (11): 515-517.

14. Löhr JM, Dominguez-Munoz E, Rosendahl J, et al. United European Gastroenterology evidence-based guidelines for the diagnosis and therapy of chronic pancreatitis ( $\mathrm{HaPa}$ nEU). United European Gastroenterol J. 2017; 5(2): 153-199. doi:10.1177/2050640616684695 15. Gullo L, Priori P, Labo G. Natural history of acute pancreatitis and its relationship to chronic pancreatitis. In Bianchi Porro G, Banks PA. Acute pancreatitis. Advances in pathogenesis, diagnosis and treatment. Masson: Milano 1984: 87-93, ISBN 978-8821416590. 16. Yadav D, O'Connell M, Papachristou GI. Natural history following the first attack of acute pancreatitis. Amer J Gastroenterol 2012; 107(7): 1096-1103.

17. Yadav D, Whitcomb DC. The role of alcohol and smoking in pancreatitis. Nat Rev Gastroenterol Hepatol 2010; 7(3): 131-145.
2) We have shown that there is no fundamental difference between the etiology of acute pancreatitis and the development of chronic pancreatitis.

3) In some patients with chronic pancreatitis after acute pancreatitis, metabolic syndrome is present. We believe that the presence of metabolic syndrome may accelerate the development of chronic pancreatitis after acute pancreatitis.

Disclosure Statement

The authors declare that they have nothing to disclose.

Funding Sources

No grants or financial support were provided.

18. Nordback I, Pelli H, Lappalainen-Lehto R, et al. The recurrence of acute-alcohol associated pancreatitis can be reduced: randomized controlled trial. Gastroenterology 2009; 136(3): 848-855.

19. Sandzen B, Rosenmuller M, Haapamaki MM, et al. First attack of acute pancreatitis in Sweden 1988-2003: incidence, aetiological classification, procedures and mortality - a register study. BMC Gastroenterology 2009; 9: 18. DOI: http//dx.doi.org /10.1186/1471-230X-9-18.

20. Berlinsson S, Sward P, Kalaitzakis E. Factors that affect disease progression after first attack of acute pancreatitis. Clin Gastroenterol Hepatol 2015; 13: 1662-1669.

21. Sankaran SJ, Xiao AY, Wu LA, et al. Frequency of progression from acute to chronic pancreatitis and risk factors: a meta-analysis. Gastroenterology 2015; 149(6): 1490-1500. e1., doi: 101053/j.gastro.2015. 07. 066.

22. Ali UA, Issa Y, Hagenaars J, et al. Risk of recurrent pancreatitis and progression to chronic pancreatitis after a first episode of acute pancreatitis. Clin Gastroenterol 2016; 14(5): 738-746. doi: 1.1016/j.cgh.2015. 12.040.

23. Burgerhart JS, van de Meeberg PC, Siersema PD, et al. Nocturnal and daytime esophageal acid exposure in normal-weight, overweight, and obese patients with reflux symptoms. Eur J Gastroenterol Hepatol 2014; 26(1): 6-10.

24. Ryan AM, Healy LA, Power DG, et al. Barrett esophagus: prevalence of central adiposity, metabolic syndrome and a proinflammatory state. Ann Surg 2008; 247: 909-915. 25. Roselli M, Lotersztajn S, Vizutti F, et al. The metabolic syndrome and chronic liver disease. Curr Pharm Des 2013; 20(31): 5010-5024.

26. Polyzos SA, Kountouras J, Mantzoros CS. The role of adiponectin in nonalcoholic fatty liver disease. Metabolism 2016; 65(8): 1062-1079.

27. Adrych K, Smoczynski M, Stelmanska E, et al. Serum adiponectin and leptin concentration in patients with chronic pancreatitis of alcoholic and nonalcoholic origin. Pancreas 2008; 36(2): 120-124

28. Van-Chen Wu, Chih-Yuan Wag. Association between non-alcoholic fatty pancreatic disease and the metabolic syndrome. Case-control retrospective study. Cardiovasc Diabetol 2013; 12: 77, doi: 10.1186/1475-2840-12-77.

29. Khatua B, El-Kurdi B, Singh VP. Obesity and pancreatitis. Curr Opinion Gastroenterol 2017; 33(5): 374-382.

30. Tariq $H$, Nayudu S, Akella S, et al. Non-alcoholic fatty pancreatic disease: A review of literature. Gastroenterol Res 2016; 9(6): 87-91.

31. Melitas C, Meiselman M. Metabolic pancreatitis: Pancreatic steatosis, hypertriglyceridemia, and associated chronic pancreatitis in 3 patients with metabolic syndrome. Case Rep Gastroenterol 2018; 12: 331-336.

32. Babinets KS, Melnyk NA, Shevchenko NO, et al. Complex therapy of chronic pancreatitis with metabolic syndrome. Wiad Lek 2018; 13(2): 1-12. 